\title{
Efek Pemberian Jus Nanas (Ananas comosus (L.) Merr) Mampu Mempercepat Penurunan Tinggi Fundus Uteri pada Ibu Postpartum
}

\section{Effects of Giving Pineapple Juice (Ananas comosus (L.) Merr) Able to Accelerate Decreased Uterine Fundus Height in Postpartum Mothers}

\author{
Margareta Rinjani $^{1 凶}$, Dela Melia Inggriani ${ }^{2}$, Iin Wahyuni ${ }^{1}$ \\ ${ }^{1}$ Sekolah Tinggi Ilmu Kesehatan Adila, Indonesia \\ ${ }^{2}$ Universitas Aufa Royhan Padangsidimpuan, Indonesia \\ ${ }^{凶}$ Coresponding author: margarethrinjani89@gmail.com
}

Kata kunci:

Jus nanas;

Ibu postpartum;

Tinggi fundus uteri.

\begin{abstract}
Abstrak
Latar belakang: Proses involusi yang tidak normal dapat menimbulkan kegagalan uterus kembali normal dan berakibat proses pengecilan uterus terhambat dan terjadi perdarahan post partum. Buah nanas dapat membantu mempercepat involusi uteri. Tujuan: membuktikan efek pemberian jus nanas (ananas comosus (L)Merr) terhadap penurunan tinggi fundus uteri (TFU) pada ibu post partum. Metode: Jenis penelitian ini merupakan studi quasi eksperimental dengan nonequivalent control group design. Kelompok eksperimen adalah ibu hamil post partum normal berjumlah 34 dan kelompok kontrol sebagai populasi penelitian dengan sampel atau kelompok eksperimen 34 orang dan kelompok kontrol 34 orang. Sampel dipilih menggunakan teknik consecutive sampling. Intervensi diberikan kepada kelompok eksperimen pada ibu setelah post partum 6-8 jam dengan konsumsi jus nanas konsentrasi $100 \%$ sebanyak 200 cc selama 7 hari. Analisis data bivariat menggunakan paired t-test dan analisis multivariat dilakukan uji regresi linier. Hasil: Hasil analisis menunjukkan rerata penurunan TFU pada kelompok eksperimen sebesar 7,78 cm dan pada kelompok kontrol sebesar 6,95 $\mathrm{cm}$ dengan selisih mean 0,83 dan terdapat penurunan TFU sesudah pemberian jus nanas (ananas comosus (L.)Merr) $(\mathrm{p}=0,000)$ pada kelompok eksperimen dibandingkan dengan kelompok kontrol. Simpulan: Pemberian jus nanas efektif menurunkan atau mengecilkan tinggi fundus uteri pada ibu post partum. Ibu post partum dianjurkan minum jus untuk mempercepat TFU kembali seperti ukuran sebelum hamil.
\end{abstract}

\begin{abstract}
Background: Abnormal involution process can cause uterine failure to return to normal and result in inhibited uterine wasting process and post partum hemorrhage. Pineapple can help accelerate uterine involution. Purpose: To prove the effect of pineapple juice (Ananas comosus (L) Merr) on decreasing the height of fundus uteri (TFU) in post partum mothers. Methods: This research is a quasi-experimental study with nonequivalent control group design. The experimental group was 34 post partum normal pregnant women and the control group was the study population with 34 samples or the experimental group and 34 control groups. Samples were selected using consecutive sampling techniques. The experimental group after 6-8 hours post partum was given an intervention of consumption of $100 \%$ pineapple juice as much as $200 \mathrm{cc}$ for 7 days. Bivariate data analysis used paired t-test and multivariate analysis performed linear regression test. Results: The results of the analysis showed the mean decrease in TFU in the experimental group was $7.78 \mathrm{~cm}$ and in the control group $6.95 \mathrm{~cm}$ with a mean difference of 0.83 and there was a decrease in TFU after administration of pineapple juice (ananas comosus (L.) Merr) $(\mathrm{p}=0,000)$ in the experimental group compared with the control group. Conclusion: The administration of pineapple juice is effective in reducing or decreasing the height of uterine fundus in post partum mothers. Post partum mothers are encouraged to drink juice to speed up TFU back to its size before pregnancy.
\end{abstract}

Copyright $(2019$ Jurnal Kesehatan Metro Sai Wawai. All rights reserved. 


\section{Pendahuluan}

Masa nifas merupakan proses kembalinya alat-alat genetalia interna dan eksterna akan berangsur-angsur pulih kembali seperti keadaan sebelum hamil, perubahan ini disebut dengan involusi. Involusi uterus atau pengerutan uterus merupakan suatu proses dimana uterus kembali ke kondisi sebelum hamil dengan bobot hanya 60 gram (Sukarni, 2014). Proses involusi jika tidak berjalan dengan normal dapat menimbulkan suatu keadaan yang dinamakan subinvolusi uteri (Ambarwati, 2010). Subinvolusio merupakan kegagalan uterus untuk mengikuti pola normal involusi sehingga proses pengecilan uterus terhambat, salah satu tandanya adalah terjadinya perdarahan (Walyani, 2015).

Angka Kematian Ibu (AKI) di provinsi Lampung tahun 2015 berjumlah 149 ibu meninggal saat proses kehamilan dan persalinan. Penyebab AKI sebanyak 46 (30,8\%) ibu meninggal karena perdarahan, 35 (23,5\%) hipertensi dalam kehamilan, 7 (4,7\%) ibu karena infeksi, 10 (6,7\%) ibu karena penyakit jantung, stroke dan lain-lain, 3 (2,0\%) karena penyakit Diabetes Melitus, dan penyebab lain terdapat 48 (32,2\%) ibu (Dinas Kesehatan Provinsi Lampung, 2016). Sedangkan, tahun 2015 di kota Bandar Lampung terdapat kasus kematian ibu sebanyak 20 ibu yang tersebar di wilayah Puskesmas Bandar Lampung, dengan penyebab AKI terjadi saat masa kehamilan terdapat 6 orang, masa persalinan 6 orang dan 8 orang meninggal saat masa nifas. Penyebab ibu meninggal saat masa nifas sebanyak 4 (50\%) ibu karena perdarahan yang merupakan salah satu tanda subinvolusi atau involusi yang gagal (Dinas kesehatan Kota Bandar Lampung, 2016).

Berbagai faktor yang mempengaruhi terjadinya involusi uteri, seperti mobilisasi dini, menyusui, usia, paritas dan status gizi (Walyani, 2015). Status gizi dapat mempercepat involusi uteri, diantaranya konsumsi buah nanas. Nanas telah digunakan sebagai tanaman obat di beberapa budaya asli dan khasiat nanas yang dikaitkan dengan bromelin. Penelitian terdahulu menunjukkan bahwa nanas merupakan buah yang memiliki pengaruh terhadap proses bersalin. Buah nanas mengandung enzim bromealin yang dapat menstimulasi pengeluaran prostaglandin. Meningkatnya kadar prostaglandin menyebabkan stimulasi kontraksi (Dewi, 2017). Selain itu, buah nanas memiliki kandungan serotonim yang juga berperan dalam merangsang kontraksi uterus (Frochlich \& Meston, 2006). Penelitian-penelitian sebelumnya telah dilakukan penelitian efek manfaat buah nanah (Ananas comosus (L.) Merr) untuk penurunan TFU pada ibu bersalin yang dilakukan oleh Rahayu \& Sugita (2015), Winda (2017) dan Lathifah, Sunarsih \& Susianah (2018). Penelitian tersebut dilakukan dengan desain quasi eksperimen menggunakan nonequivalent control group design menemukan terdapat pengaruh yang signifikansi setelah pemberian buah nanas, terjadi penurunan tinggi fundus antara kedua kelompok intervensi dan kelompok kontrol $(\mathrm{p}=0,000)$. Namun, penelitian tersebut belum mengendalikan variabel luar atau perancu yang dapat mempengaruhi hasil penelitian. Dengan demikian, perlu penelitian untuk memperoleh hasil validitas yang lebih tinggi, yaitu studi intervensi efek buah nanas (Ananas comosus (L.)Merr) terhadap penurunan tinggi fundus uteri ibu post partum. Walaupun desain penelitian sama, yaitu quasi eksperimen, namun penelitian ini melakukan pengendalian variabel luar (confounding) dengan melakukan analisis multivariat.

Survei pendahuluan yang dilakukan di wilayah kerja Puskesmas Rajabasa Indah tahun 2017 terdapat 1113 ibu bersalin dan tahun 2018 pada bulan Januari sampai dengan bulan Oktober sasaran ibu bersalin sebanyak 946 ibu, sehingga rata-rata setiap bulan jumlah persalinan sebanyak 95 orang. Hasil wawancara dari 3 orang ibu post partum mengatakan ibu belum pernah mengkonsumsi jus nanas baik dari hamil sampai masa nifas ini, bidan maupun petugas hanya menyarankan ibu untuk melakukan gerakan ringan seperti berjalan atau imobilisasi dini, menyusui bayi serta pola makanan sehari-hari, dan belum pernah memberikan jus nanas. Fenomena yang terjadi, belum banyak tenaga kesehatan dalam melakukan perawatan nifas menggabungkan terapi nonfarmakologi atau komplementer pemberian jus nanas, sedangkan manfaat dari pemberian jus nanas sangat banyak terutama dalam proses involusi uteri. 
Artikel ini merupakan hasil penelitian dengan tujuan membuktikan efek atau manfaat jus nanas (Ananas comosus (L.)Merr) dalam mempercepata penurunan tinggi fundus uteri ibu post partum.

\section{Metode}

Rancangan penelitian menggunakan quasi eksperimental dengan nonequivalent control group design. Pemilihan desain dengan pertimbangan pembagian subyek secara random tidak memungkinkan dan kurang etis (Murti, 2016). Rancangan ini digunakan untuk membuktikan efek atau manfaat jus nanas (Ananas comosus (L.)Merr) terhadap penurunan tinggi fundus uteri ibu post partum. Tempat dilaksanakan di Bidan Praktek Mandiri (BPM) wilayah Puskesmas Rajabasa Indah Kota Bandar Lampung yang dilaksanakan pada bulan September-November tahun 2019. Sampel penelitian ibu postpartum di wilayah Puskesmas Rajabasa Indah Kota Bandar Lampung yang dihitung menggunakan rumus beda dua mean diperoleh jumlah sampel minimal 17 orang untuk masing-masing kelompok eksperimen dan kelompok kontrol atau jumlah total sampel 34 orang. Sampel dipilih berdasarkan kriteria inklusi antara lain ibu post partum, persalinan normal, melakukan IMD (Inisiasi Menyusui Dini), tidak memiliki pantangan makanan, tidak mengalami komplikasi, melakukan mobilisasi dini dan secara kooperatif bisa diajak komunikasi dan mampu makan secara oral dalam bentuk lunak atau biasa. Sedangkan, kriteria eksklusi sampel dilakukan, jika ibu postpartum yang selama intervensi meninggalkan atau pindah rumah yang tidak dapat dijangkau, mengalami komplikasi kehamilan dan meminta keluar dari sampel penelitian.

Prosedur penelitian dimulai dengan (1) pengukuran penurunan TFU pada kedua kelompok sebelum diberikan intervensi (pretest) dilakukan pada 6-8 jam setelah persalinan. Alat pengukur TFU menggunakan pita pengukur (metlin) dalam centimeter; (2) Kelompok eksperimen berikan jus nanas sebanyak $200 \mathrm{cc}$ pada kelompok intervensi dengan cara nanas dijuicer dengan tingkat konsentrasi $100 \%$ dan jus yang didapatkan sebanyak $200 \mathrm{cc}$, jus nanas dibuat murni tanpa tambahan air atau gula. Pemberian jus nanas selama 7 hari; (3) Post pengukuran TFU dilakukan kembali setiap hari setelah 4-6 jam pemberian jus nanas, kemudian dicatat dilembar observasi pemantauan penurunan TFU. Adapun kelompok kontrol diberikan intervensi dengan memberikan asuhan sayang ibu sesuai standar pelayanan masa nifas, kemudian dilakukan prosedur pengukuran sebagaimana kelompok eksperimen.

Analisis data hasil intervensi menggunakan paired t-test untuk menjawab tujuan penelitian. Hasil Data dilakukan uji normalitas untuk menentukan uji statistik. Jika, masing-masing variabel dengan nilai skewness berbanding standar error $\leq 2$, maka uji statistik tetap menggunakan paired $t$-test. Pengendalian faktor luar (confounding) dilakukan dengan analisis multivariat menggunakan uji regresi linier dengan memasukan variabel-variabel yang dapat berpenagruh antara lain usia, laktasi dan IMT. Pelaksanaan penelitian dilakukan setelah memperoleh lulus kaji etik (ethical clearance) penelitian dari Komisi Etik Politeknik Kesehatan Tanjung Karang Nomor 09/EC/KEP-TJK/II/2018, izin penelitian dari tempat penelitian dan informed consent dari responden penelitian.

\section{Hasil}

\section{Karakteristik Responden}

Hasil analisis pada tabel 1 menunjukan kelompok eksperimen dengan usia terbanyak adalah usia produktif, yaitu 20-35 tahun (88,2\%), sedangkan pada kelompok kontrol seluruh responden berusia 20-35 tahun (100\%) dan baik kelompok eksperimen maupun kelompok kontrol dengan laktasi ibu seluruhnya $>8 \mathrm{x} /$ hari. Adapun IMT pada kelompok eksperimen terdapat 58,8\% dengan IMT lebih dari normal dan kelompok kontrol terdapat 52,9\% dengan IMT cukup atau normal.

\section{Uji normalitas data}

Hasil uji normalitas pada tabel 2 menunjukkan masing-masing variabel dengan nilai skewness berbanding standar error $\leq 2$, maka data berdistribusi normal. Sehingga, uji statistik tetap menggunakan 
paired $t$-test. Tabel 3 menunjukkan bahwa pada kelompok eksperimen diperoleh rerata nilai penurunan TFU sebelum intervensi 13,22 cm (min-max: 12,4 -14,3 cm; SD 0,63 cm). Sedangkan, rerata nilai TFU sesudah intervensi turun menjadi 5,30 cm (min-max: 4,8 - 6,4 cm; SD 0,54 cm).

Tabel 1.

Distribusi Frekuensi Karakteristik Responden

\begin{tabular}{lllcc}
\hline Kelompok (n=17) & \multicolumn{1}{c}{ Variabel } & \multicolumn{1}{c}{ Kategori } & Jumlah $(\mathbf{n}=\mathbf{1 7})$ & $\mathbf{\%}=\mathbf{1 0 0}$ \\
\hline Eksperimen & Usia & $20-35$ tahun & 15 & 88.2 \\
& & $>35$ tahun & 2 & 11.8 \\
& Laktasi & $>$ 8x sehari & 17 & 100.0 \\
& IMT & Normal / sesuai IMT & 7 & 41.2 \\
& & Lebih dari IMT & 10 & 58.8 \\
\hline Kontrol & Usia & 20-35 tahun & 17 & 100.0 \\
& Laktasi & $>8 x$ sehari & 17 & 100.0 \\
& \multirow{2}{*}{ IMT } & Normal / sesuai IMT & 8 & 47.1 \\
& & Lebih dari IMT & 9 & 52.9 \\
\hline
\end{tabular}

Tabel 2

Uji Normalitas Data Penelitian

\begin{tabular}{lcccc}
\hline \multicolumn{1}{c}{ Kelompok } & Skewness & Std. Error & Skewness : Std.Error & Ket \\
\hline Eksperimen sebelum & 0.539 & 0,550 & 0.98 & Normal \\
Eksperimen sesudah & 0,765 & 0,550 & 1,39 & \\
Kontrol sebelum & 0,715 & 0,550 & 1,3 & Normal \\
Kontrol sesudah & 0,164 & 0,550 & 0,29 & \\
\hline
\end{tabular}

Tabel 3

Hasil pengukuran penurunan TFU sebelum dan sesudah pemberian jus nanas pada kelompok eksperimen

\begin{tabular}{lcccc}
\hline \multicolumn{1}{c}{ Kelompok } & Mean & Minimum & Maximum & Standar Deviasi \\
\hline Eksperimen & & & & \\
$\quad$ Sebelum & 13,22 & 12,4 & 14,3 & 0,63 \\
$\quad$ Sesudah & 5,447 & 4,8 & 6,4 & 0,54 \\
$\quad$ Kontrol & & & & 0,65 \\
$\quad$ Sebelum (pretest) & 13,13 & 12,4 & 14,3 & 0,64 \\
$\quad$ Setelah (Posttest) & 6,1 & 5,2 & 7,3 & \\
\hline
\end{tabular}

Tabel 3 menunjukkan bahwa pada kelompok eksperimen diperoleh rerata nilai penurunan TFU sebelum intervensi $13,22 \mathrm{~cm}$ dan sesudah intervensi turun menjadi $5,30 \mathrm{~cm}$. Sedangkan, pada kelompok kontrol diperoleh rerata nilai penurunan TFU sebelum intervensi $13,13 \mathrm{~cm}$ dan sesudah intervensi turun menjadi $6,10 \mathrm{~cm}$.

\section{Hasil analisis pengaruh jus nanas terhadap penurunan TFU sebelum dan sesudah intervensi}

Hasil analisis paa tabel 4 menunjukan hasil analisis bahwa terdapat perbedaan nilai penurunan TFU sebelum dan sesudah diberikan jus nanas pada Kelompok eksperimen $(p=0,000)$. Sedangkan, pada kelompok kontrol dari hasil analisis menunjukkan terdapat perbedaan nilai penurunan TFU sebelum dan sesudah dilakukan IMD ( $\mathrm{p}=0,000$ ). Rerata penurunan TFU pada kelompok eksperimen sebesar 7,78 cm dan pada kelompok kontrol sebesar $6,95 \mathrm{~cm}$ dengan selisih mean 0,83 dan signifikansi $p=0,000$ sehingga dapat disimpulkan terdapat perbedaan penurunan TFU kelompok eksperimen dan kelompok kontrol. 


\section{Analisis variabel luar (confounding) berpengruh terhadap penurunan tinggi fundus uteri}

Analisis variabel perancu untuk mengetahui pengaruh murni antara variabel bebas yang diduga berpenagruh terhadap penurunan TFU ibu pascasalin yang dilakukan karena rancangan penelitian quasi eksperiment. Variabel perancu yang dimasukkan analisis multivariat menggunakan uji regresi logistik linier karena dianggap bisa mempengaruhi hasil penelitian adalah usia, laktasi, indeks masa tubuh (IMT).

Tabel 5 merupakan ringkasan hasil uji variabel confounding menunjukan ternyata variabel usia yang memiliki nilai $p$-value $>0,05$ adalah variabel usia, laktasi dan IMT. Variabel dengan nilai $\mathrm{p}$ value tertinggi, muali variabel laktasi, IMT dan usia. Sehingga, ketiga variabel tersebut dikeluarkan dari model, karena tidak terdapat perubahan nilai Coefisien $\mathrm{B}>10 \%$ (lihat tabel 6). Tabel 6 sebagai model multivariat akhir pengaruh variabel confounding variabel menunjukkan pengaruh pemberian jus nanas terhadap penurunan TFU $(\mathrm{p}=0,001)$ dengan faktor usia, laktasi dan IMT bukan sebagai variabel confounding.

Tabel 4.

Hasil analisis Penururan TFU sebelum dan sesudah intervensi menggunakan paired-test pada kelompok eksperimen dan kelompok kontrol

\begin{tabular}{lccccc}
\hline \multicolumn{1}{c}{ Kelompok } & n & Beda Mean & SD & T-test & $\boldsymbol{P}$-Value \\
\hline $\begin{array}{l}\text { TFU sebelum - sesudah eksperimen } \\
\text { pada kelompok eksperimen }\end{array}$ & 17 & 7.7824 & 0.727 & 44.115 & 0,000 \\
$\begin{array}{l}\text { TFU sebelum - sesudah eksperimen } \\
\text { pada kelompok kontrol }\end{array}$ & 17 & 6.9529 & 0.501 & 57.176 & 0,000 \\
\hline
\end{tabular}

Tabel 5.

Model awal analisis multivariat pengaruh variabel confounding terhadap penurunan TFU

\begin{tabular}{|c|c|c|c|c|}
\hline Variabel & B & Sandart Error & $\mathbf{T}$ & Sig. \\
\hline Pemberian jus nanas & 0,663 & 0,185 & 3,039 & 0,005 \\
\hline Usia & 0,572 & 0,464 & 1,233 & 0,227 \\
\hline Laktasi & 0,014 & 0,302 & 0,047 & 0,963 \\
\hline IMT & 0,063 & 0,214 & 0,294 & 0,771 \\
\hline
\end{tabular}

Tabel 6.

Model Akhir Multivariat Pengaruh Variabel confounding terhadap penurunan TFU

\begin{tabular}{rcccc}
\hline Variabel & B & Sandart Error & T & Sig. \\
\hline Pemberian jus nanas & 0,735 & 0,205 & 3,594 & 0,001 \\
\hline
\end{tabular}

\section{Pembahasan}

Penelitian ini bertujuan untuk mengetahui pengaruh pemberian jus nanas(Ananas commosus (L.)Merr) terhadap penurunan tinggi fundus uteri pada ibu postpartum. Hasil penelitian memperlihatkan terdapat penurunan TFU sesudah pemberian jus nanas (ananas comosus (L.)Merr) $(\mathrm{p}=0,000)$. Kelompok eksperimen diberikan jus nanas sebanyak 200 cc dengan cara nanas dijuicer dengan tingkat konsentrasi $100 \%$ atau jus nanas dibuat murni tanpa tambahan air atau gula.

Buah nanas (Ananas comosus) dengan komposisi banyak kandungan zat gizi meeliputi vitamin A, kalsium, fosfor, magnesium, besi, natrium, kalium, dekstrosa, sukrosa, dan enzim bromelin 
(bromelain). Enzim bromelin terdiri atas 95\%-campuran protease sistein, yang dapat menghidrolisis protein (proteolisis) dan tahan terhadap panas (SetyawatiI \& Yulihastuti, 2011). Ekstrak buah nanas muda diantara komposisinya banyak terdapat enzim bromelin dibanding nanas tua (Apsari, Purwantiningrum, \& Soeharto, 2014).

Nanas merupakan salah satu tanaman obat telah digunakan di beberapa budaya asli dan khasiat nanas yang dikaitkan dengan bromelin. Bromelin telah diketahui fungsinya semenjak 1876. Bromelin awal digunakan sebagai agen terapi komplementer pada tahun 1957 oleh Heinicke dan Gortner yang menemukan kandungan konsentrasi bromelin yang tinggi pada stem nanas (Silaban \& Rahmanida, 2016). Bromelin terbukti mempunyai berbagai khasiat dibidang kesehatan, antara lain memiliki efek terhadap ibu mengandung dan ibu melahirkan. Kerja bromelin dengan mekanisme kerja berdasarkan dua tipe prostaglandin, yaitu prostaglandin proinflamasi (PGE2 dan PGF2) dan prostaglandin antiinflamasi (PGE1). Prostaglandin proinflamasi melakukan stimulasi peradangan (inflamasi), agregasi trombosit, dan memperkecil pembuluh darah (vasokonstriksi), sedangkan prostaglandin antiinflamasi bekerja secara berlawanan atau sebaliknya (Wuryanti, 2004). Enzim bromelin dapat melakukan stimulasi peningkatan prostaglandin dan kontraksi uterus. Prostaglandin tidak hanya mempunyai efek pada kontraksi uterus saat hamil dan melahirkan, tapi juga memberikan efek terhadap kontraksi uterus tidak hamil. Saat ovulasi, kandungan progesteron meningkat dan menstimulasi pengeluaran prostaglandin PGF2-alfa dari endometrium, kemudian menstimulasi kontraksi miometrium. Sehingga, enzim bromelin memperlihatkan memiliki pengaruh menstimulasi kontraksi uterus (Cunningham, 2012).

Tinggi fundus uteri menunjukkan kecenderungan menurun dengan meningkatnya lamanya frekuensi pemberian jus nanas. Efek jus nanas dalam menurunkan TFU karena adanya kandungan enzim Bromelin dalam meningkatkan aktivitas kerja hidrolitik pada jaringan ikat terutama dengan kolagen. Aktivitas kolagenase bromelin dengan melakukan hidrolisis kolagen kemungkinan melalui akumulasi hidroksiprolin (Ionescu et al., 2008). Ekstrak buah nanas yang dikonsumsi secara berulang mempunyai pengaruh atau menyebabkan kandungan enzim bromelin yang cukup tinggi dalam darah dibanding nanas muda. Hidrolisis kolagen oleh bromelin terutama kolagen tipe III mempunyai efek dinding uterus menjadi lunak dan jaringan ikat mengendor. Keadaan ini mempercepat dan memudahkan proses involusio uteri. Kolagen yang terhidrolisis karena enzim bromelin menyebabkan uterus sangat lunak. Degradasi kolagen karena bromelin berefek pada penurunan berat badan, pertumbuhan dan perkembangan uterus secara total. Kolagen merupakan komponen penyusun dinding arteri, vena dan kapiler tubuh dapat mengakibatkan kekuatan, struktur dan fleksibilitas vaskuler, agar transportasi darah sistemik dapat efektif (Sherwood, 2010).

Penelitian ini memperlihatkan terdapat percepatan penurunan TFU ibu postpartum sebelum dan sesudah diberikan jus nanas $200 \mathrm{cc}$ selama 7 hari pada kelompok eksperimen $(\mathrm{p}=0,000)$ dibandingkan kelompok kontrol. Rerata penurunan TFU pada kelompok eksperimen sebesar 7,78 cm dan pada kelompok kontrol sebesar $6,95 \mathrm{~cm}$ dengan nilai mean $0,83 \mathrm{~cm}$. Hasil ini setelah dilakukan pengontrolan terhadap variabel luar dengan analisis multivariat. Model multivariat akhir pengaruh variabel confounding variabel menunjukkan pengaruh pemberian jus nanas terhadap penurunan TFU $(p=0,001)$ dengan faktor usia, laktasi dan IMT bukan sebagai variabel confounding. Sedangkan, penelitianpenelitian sebelumnya dilakukan oleh Rahayu \& Sugita (2015), Winda (2017) dan Lathifah, Sunarsih \& Susianah (2018) memperoleh hasil terdapat percepatan penurunan TFU setelah diberikan intervensi nanas pada kelompok eksperimen dibandingkan dengan kelompok kontrol, namun dilakukan dengan desain penelitian, yaitu quasi eksperimen yang tidak mengendalikan faktor luar (confounding). Keterbatasan penelitian ini, belum melakukan pengendalian semua variabel luar yang mempunyai efek terhadap proses involusi dan penurunan TFU, seperti mobilisasi dini dan ambulasi serta lama persalinan. Perlunya penelitian lanjutan, untuk mendapatkan hasil gold dengan intervensi ekstrak nanas dengan 
mengendalikan faktor-faktor luar secara ketat. Selain itu, lama pemberian jus nanas perlu ditambah menjadi minimal 10 hari sesuai lama proses involusi secara fisiologis.

Sesuai penemuan penelitian ini, pemberian jus nanas (Ananas comosus (L.)Merr) memiliki efek menurunan TFU lebih cepat dibandingkan tanpa diberikan jus nanas, maka Bidan atau tenaga kesehatan lainnya dapat menjadikan sebagai terapi komplementer atau non formakologi yang diproses secara alami tanpa melibatkan penggunaan bahwa kimia, sehingga dapat mempercepat proses involusi uteri dan mencegah terjadinya komplikasi persalinan.

\section{Simpulan dan Saran}

Pemberian jus nanas (Ananas Comosus (L.) Merr memberikan efek penurunan TFU pada ibu postpartum, karena adanya kandungan enzim bromelin. Pemberian jus nanas sebanyak $200 \mathrm{cc}$ murni selama tujuh hari mempercepat involusi uteri $0,83 \mathrm{~cm}$. Implikasi pada ibu bersalin pada proses involusi uteri dapat dilakukan percepatan penurunan TFU dengan dibantu terapi komplementer melalui jus nanas. Konsumsi jus nanas perlu ditambah menjadi 10 hari sesuai lama proses involusi untuk memperoleh efek penurunan TFU yang optimal.

\section{Referensi}

Ambarwati, E.R, \& Rismintari, Y.S. (2010). Asuhan kebidanan pada masa nifas. Yogjakarta: Nuha Medika

Apsari, D.D., Purwantiningrum, D.A., Soeharto, S. (2014). Perbandingan Efek Pemberian Ekstrak Buah Nanas Muda dan Ekstrak Buah Nanas Tua Terhadap Kontraktilitas Uterus Terpisah Marmut (Cavia porcellus). Majalah Kesehatan. 1(2). 117-124. Retreived from: https://majalahfk.ub.ac.id/index.php/mkfkub/article/view/32

Cunningham, G. F., Leveno, K. J., Bloom, S. L., Hauth, J. C., Rouse, D.J., Spong, C. Y.,et al. (2012). Obstetri williams. Edisi 23. Jakarta: EGC

Dewi, R. (2017). Efek pemberian ekstrak buah nanas muda dan tua (ananas. C. L.merr) terhadap kejadian abortus pada mencit (mus musculus). Jurnal Bahana Kesehatan Masyarakat.1(1). 2017, 1-7. Retrieved from: http://journal.poltekkesjambi.ac.id/index.php/JBKM/issue/view/2

Dinas Kesehatan Kota Bandar Lampung (2016). Profil Kesehatan Kota Bandar Lampung 2015. Bandar Lampung: Dinas Kesehatan Kota Bandar Lampung

Dinas Kesehatan Provinsi Lampung (2016). Profil Kesehatan Provinsi Lampung 2015. Bandar Lampung: Dinas Kesehatan Provinsi Lampung

Frochlich, P.H. \& Meston, C. M. (2006). Evidence that serotonin affect female sexual functioning via pheriperal mechanism. Physiology and Behavior. 71(3-4). 2000:383-393 DOI: 10.1016/s0031-9384(00)00344-9

Ionescu, A., Aprodu, I., \& Pascaru, G. (2008). Effect of papain and bromelinon muscle and collagenproteins in beef meat. Fascicle VI - Food Technology, NewSeries II (XXXI): 9-16. Retrieved from: https://pdfs.semanticscholar.org/22dc/7fc79a5b755bc2c3d401413747f9617f86ae.pdf

Lathifah, N. S., Sunarsih \& Susianah, T. (2018). Perbedaan penurunan tinggi fundus uteri pada ibu nifas yang dilakukan inisiasi menyusui dini (IMD) dan imd dengan diberikan jus nanas di BPM Tias Susianah Lampung Utara Tahun 2018. Jurnal Kebidanan dan Kesehatan Tradisional. 3(2). 2018. 57-106. Retreived from: http://jurnal.poltekkes-solo.ac.id/index.php/JKK/article/view/441

Rahayu, R. D. (2015). Perbedaan penurunan tinggi fundus uteri setelah pemberian jus nanas pada ibu post partum di Kabupaten Klaten. Bidan Prada: Jurnal Publikasi Kebidanan Akbid YLPP Purwokerto, 6(1). Retrieved from: http://ojs.akbidylpp.ac.id/index.php/Prada/article/view/123

SetyawatiI \& Yulihastuti, D. A. (2011). Penampilan reproduksi dan perkembangan skeleton fetus mencit setelah pemberian ekstrak buah nanas muda. Jurnal Veteriner. 2011; 12(3):192-9. Retreived from: https://ojs.unud.ac.id/index.php/jvet/article/view/3510

Sherwood C. (2010). Collagen functions. Retreived from: http://www.livestrong.com/article/78360collagenfunctions 
Efek Pemberian Jus Nanas (Ananas comosus (L.) Merr) Mampu Mempercepat Penurunan Tinggi Fundus Uteri

Silaban, I. \& Rahmanisa, S. (2016). Pengaruh enzim bromelin buah nanas ( ananas comos) terhadap awal kehamilan. Jurnal MAJORITY. 5(4). 2016. 80-85. Retrieved from: https://juke.kedokteran.unila.ac.id/index.php/majority/article/view/889

Sukarni, I. (2014). Patologi: kehamilan, persalinan, nifas, dan neonatus resiko tinggi. PT.Nuha Medika, Yogyakarta.

Walyani, E. S., \& Purwoastuti, E. (2015). Asuhan kebidanan masa nifas dan menyusui. PT. Pustaka Baru, Yogyakarta.

Harianja, W.Y., Setiani, O., Umaroh, Widyawati, M.N., Mashoedi, I.D., \& Pujiastuti, S. E. (2017). The impact of pinepple juice on fundal height in primigravida mothers during postpartum priod. Belitung Nursing Journal, Volume 3(2)April 2017 :134-141. DOI: https://doi.org/10.33546/bnj.76

Wuryanti (2004). Isolasi dan penentuan aktivias spesifik enzim bromelin. Jurnal Kimia Sains dan Aplikasi. 7(3). 2004:83-7. DOI: https://doi.org/10.14710/jksa.7.3.78-82 